\title{
NEEDS ASSESSMENT ACTIVITY REPORT: APRIL 1995
}

Date Published

April 1995

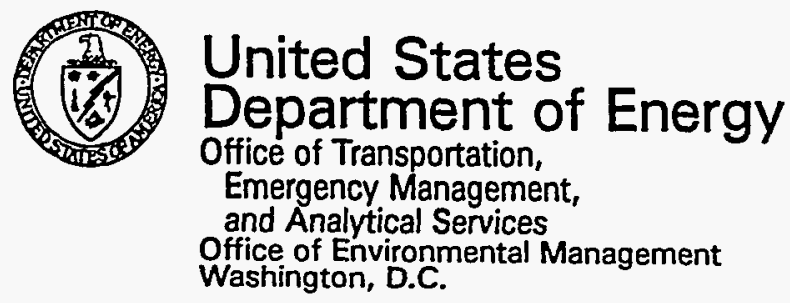
ADS Number: 2601
Date: April 1995 Revision No. 0

Office of Transportation Emergency Management

Office of Environmental Management

Washington, D.C.

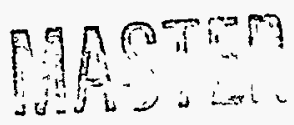

Approved for Public Release 


\section{DISCLAIMER}

This report was prepared as an account of work sponsored by an agency of the United States Government. Neither the United States Government nor any agency thereof, nor any of their employees, make any warranty, express or implied, or assumes any legal liability or responsibility for the accuracy, completeness, or usefulness of any information, apparatus, product, or process disclosed, or represents that its use would not infringe privately owned rights. Reference herein to any specific commercial product, process, or service by trade name, trademark, manufacturer, or otherwise does not necessarily constitute or imply its endorsement, recommendation, or favoring by the United States Government or any agency thereof. The views and opinions of authors expressed herein do not necessarily state or reflect those of the United States Government or any agency thereof. 


\section{DISCLAIMER}

Portions of this document may be illegible in electronic image products. Images are produced from the best available original document. 
DOE/RL-95-43 REV 0

\section{EXECUTIVE SUMMARY}

As part of a U.S. Department of Energy Headquarters task (DOE-HQ), the Packaging Operations and Development Group within Westinghouse Hanford Company (WHC) has assessed the packaging needs of many DOE sites. These assessments have involved site visits and meetings with personnel involved with transportation and packaging of hazardous materials. By March 1995, 20 DOE facilities had been visited. As a result, these sites have been informed of some of the packaging activities that DOE has sponsored and is sponsoring, have been apprised of the affects of upcoming changes to transportation regulations, have discussed their short-term packaging needs, and have shared unique packaging they have developed which may be of use to other DOE facilities. Program successes include discovery of a need for a reusable Type A liquid sample packaging and its development within another DOE task, establishing communications pathways between DOE sites that have similar transportation and packaging needs, and starting to establish a centralized packaging clearinghouse that will coordinate DOE Complex needs and improve the cost-effectiveness of transportation and packaging activities.

The main recommendation of this report is to centralize and coordinate all packaging activities within one organization. This centralization would greatly improve the cost-effectiveness and efficiency of packaging across the DOE Complex and has the potential to save millions of dollars per year. This report also recommends that the Needs Assessment activity continue to pursue the strategy of visiting DOE sites to meet with their transportation and packaging personnel. These visits will ensure that DOE needs are met, communications 


\section{DOE/RL-95-43 REV 0}

pathways between DOE sites are established, and redundant packaging development is

identified. The site visits should be expanded to include meetings with the long-range and strategic planners at each site, and at the DOE-HQ level, to ensure that all future transportation and packaging needs are identified early enough to allow adequate transportation assessment and packaging development. This activity could become a permanent conduit for information and will ensure that all future DOE transportation and packaging needs are satisfied. 
DOE/RL-95-43 REV 0

CONTENTS

1.0 INTRODUCTION $\ldots \ldots \ldots \ldots \ldots \ldots \ldots \ldots \ldots \ldots \ldots$

2.0 SITE PRESENTATION FORMAT $\ldots \ldots \ldots \ldots \ldots \ldots \ldots \ldots \ldots$

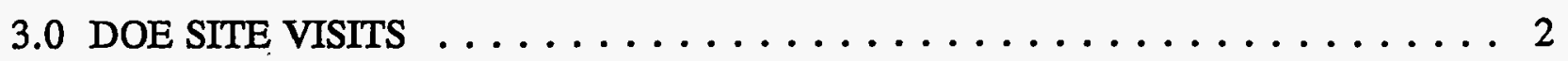

3.1 WASTE ISOLATION PILOT PLANT $\ldots \ldots \ldots \ldots \ldots \ldots$

3.2 ROCKY FLATS ENVIRONMENTAL TECHNOLOGY SITE . . . . . . 2

3.3 SAVANNAH RIVER SITE $\ldots \ldots \ldots \ldots \ldots \ldots \ldots \ldots$

3.4 OAK RIDGE NATIONAL ENGINEERING LABORATORY $\ldots \ldots \ldots$

3.5 IDAHO NATIONAL ENGINEERING LABORATORY $\ldots \ldots \ldots \ldots \ldots$

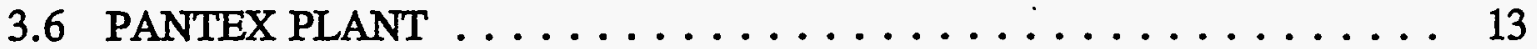

3.7 LOS ALAMOS NATIONAL LABORATORY . . . . . . . . . . . 15

3.8 LAWRENCE LIVERMORE NATIONAL LABORATORY . . . . . . . . 18

3.9 SANDIA NATIONAL LABORATORY - LIVERMORE $\ldots \ldots \ldots \ldots$

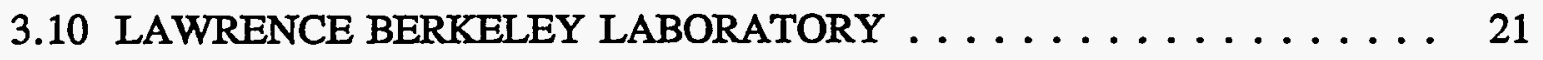

4.0 FUTURE FY 1995 NEEDS ASSESSMENT ACTIVITY . . . . . . . . . . 22

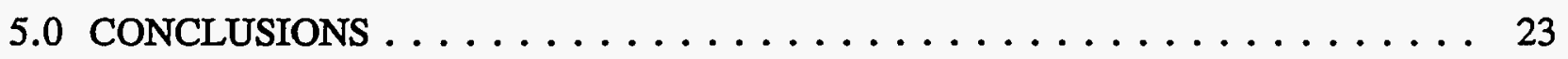

6.0 RECOMMENDATIONS $\ldots \ldots \ldots \ldots \ldots \ldots \ldots \ldots \ldots \ldots \ldots \ldots$

7.0 REFERENCES . . . . . . . . . . . . . . . . 26 


\section{LIST OF TERMS}

DOE

DOE-HQ

DOT

FY

HEUN

INEL

LLNL

NRC

POP

RCRA

SARP

SQIG

TRU

WHC

WIPP
U.S. Department of Energy

U.S. Department of Energy, Headquarters (Washington D.C.)

U.S. Department of Transportation

fiscal year

highly enriched uranyl nitrate

Idaho National Engineering Laboratory

Lawrence Livermore National Laboratory

U.S. Nuclear Regulatory Commission

performance oriented packaging

Resource Conservation and Recovery Act

safety analysis report for packaging

Suppliers Quality Information Group

transuranic

Westinghouse Hanford Company

Waste Isolation Pilot Plant 


\section{NEEDS ASSESSMENT ACTIVITY REPORT: APRIL 1995}

\subsection{INTRODUCTION}

The Packaging Operations and Development Group in the Transportation and Packaging Division of Westinghouse Hanford Company (WHC) started performing an assessment of the packaging needs for U.S. Department of Energy (DOE) in fiscal year (FY) 1994. This assessment has been funded by the Office of Transportation, Emergency Management, and Analytical Services within the DOE Office of Environmental Management.

This activity originated as a result of several packaging development tasks initiated by the Packaging Operations and Development Group in FY 1993. The introductory phase of those packaging development efforts typically included needs assessments that involved searching the DOE Complex for information relevant to the specific task. During those searches it was found that a wide range of packaging and associated transportation needs had no formal mechanism for being addressed by DOE. Therefore, the Packaging Operations and Development Group requested DOE to begin a task to investigate the different DOE programmatic packaging requirements and needs, evaluate the determined needs as compared to existing packaging resources, and evaluate the needs compared to potential DOE developmental efforts. DOE approved the Packaging Operations and Development Group request, and the Needs Assessment began in FY 1994. The first ten Needs Assessment sites visits occurred from March to June 1994 and are detailed in DOE/RL-94-106, Revision 1, Needs Assessment Activity Report (DOE/RL 1994).

\subsection{SITE PRESENTATION FORMAT}

At the opening of each meeting, the role of the Office of Transportation, Emergency Management, and Analytical Services within DOE and its role in packaging development activities is discussed. Specific examples of packaging developed, or under development, within DOE - such as the Tritium Waste Package, Type A liquid sample packaging, and Type B Drum - are then presented. The presentation has evolved as new packaging that may have use throughout the DOE Complex are discovered or common needs are recognized. Ongoing regulatory activities including Performance Oriented Packaging (POP) and other possible regulatory revisions are discussed. During these meetings, an active discussion between the presenters and the attendees is encouraged and always occurs. After the presentations are complete, the sites are then asked to discuss any packaging rieeds they may have that are not being satisfied and any packaging they may have developed which could be of use to other DOE facilities. Finally, any unique packaging or shipping facilities are visited. 
The attendees at these meetings have, in general, been personnel in the packaging and transportation function within the site organization. Other personnel from site organizations (e.g., waste management or remediation) that make large numbers of shipments or have future packaging needs also attend these meetings. Representatives from local DOE offices have sometimes attended the meetings or have been visited separately after the meeting. The format of the meetings has been successful in gathering the most information possible from each DOE site. Site visits typically last for half a day, but some visits have lasted for an entire day.

\subsection{DOE SITE VISITS}

\subsection{WASTE ISOLATION PILOT PLANT}

The meeting at the Waste Isolation Pilot Plant (WIPP) was scheduled to discuss the Type B Drum project, and the Needs Assessment. The discussion centered on features that should be incorporated into the Type B Drum design to make it more acceptable for use at WIPP and by small sites. Features of the NuPac 72-B container that are currently being developed by WIPP and Vectra for use with remote-handled transuranic waste were discussed. The process of obtaining Nuclear Regulatory Commission (NRC) certification of the TRUPACT II container for use was also discussed, as well as restrictions in the packaging contents that were made to gain NRC certification (e.g., the 325 gram limit for plutonium). Finally, WIPP stated that they did not think additional packagings were needed to meet the needs of the Transuranic Waste Program because packaging needs would be satisfied through use of the TRUPACT II, in its current configuration and as modified by Rocky Flats (see Section 3.2.1), the NuPac 72-B, and the Type B Drum, once those packagings are certified for use by the NRC.

\subsection{ROCKY FLATS ENVIRONMENTAL TECHNOLOGY SITE}

\subsubsection{Rocky Flats Packaging Development}

Rocky Flats has a small packaging design group that is currently developing $15 \mathrm{~cm}$ (6 in.) and $30 \mathrm{~cm}(12$ in.) diameter pipes that will fit inside each of the drums in a TRUPACT II container. These pipes are intended to enable a user of the TRUPACT II to increase the plutonium loading from 325 grams total to $2.8 \mathrm{~kg}$ (200 grams within each of the TRUPACT II's 14 drums). Rocky Flats also intends to begin the development of two overpack-like containers for low-level mixed waste. These overpacks will be used around existing waste packaging that may not be leak-tight because the packagings are retrieved from an onsite burial ground for disposal elsewhere. 
The dimensions of these overpacks will be $104 \mathrm{~cm} \times 224 \mathrm{~cm} \mathrm{x} 124 \mathrm{~cm}(41 \mathrm{in}$. x 88 in. x 49 in.) and $163 \mathrm{~cm} \times 152 \mathrm{~cm} \times 127 \mathrm{~cm}(64$ in. $\times 60$ in. $\times 50$ in.), and are based on the size of the existing packaging.

\subsubsection{Rocky Flats Packaging Needs}

Rocky Flats identified the following present and future packaging needs.

- $3,000 \mathrm{~L}$ (793 gal) of highly enriched (up to 93\%) uranyl nitrate (HEUN) liquid is currently stored at the site. The site plans to ship the HEUN $10 \mathrm{~L}$ ( 3 gal) at a time inside of a Babcock \& Wilcox 5X22 container. Follow-up discussions with Rocky Flats indicated that they would not ship larger quantities of HEUN in a single packaging even if such a packaging was available due to criticality concerns. The HEUN will be shipped to Oak Ridge National Laboratory for processing. At present, Rocky Flats does not have a deadline for shipping the HEUN. However, they are concerned that the State of Colorado may designate the HEUN as a Resource Conservation and Recovery Act, 42 USC 6901 et seq. (RCRA), waste, which would require obtaining a RCRA storage permit and certifying the building containing the HEUN as RCRA storage facility. Rocky Flats would prefer to ship the HEUN to Oak Ridge before the HEUN is designated as a RCRA waste.

- 14 metric tons of weapons grade plutonium is currently stored onsite. This plutonium is stored in containers that do not meet new DOE-HQ criteria (less than $4.5 \mathrm{~kg}$ of plutonium metal per container, less than $5.1 \mathrm{~kg}$ of plutonium oxide per container) that took effect in late 1994. Rocky Flats is working with Los Alamos National Laboratory to develop containers that do meet the new storage criteria. The final disposition of this plutonium has not yet been determined by DOE. If this material is shipped offsite, transportation packaging will be required. One possibility is shipping the current storage containers, with one or two more layers of containment added to the packaging, inside of the SAFEKEG container, once the SAFEKEG is certified by the NRC. The plutonium shipping containers developed by Savannah River that are being reviewed by DOE-HQ for certification (formerly known as the Chalfant packagings, now known as the $9972,9973,9974$, and 9975 containers) could also be used. The Type B Drum, which is currently under development, may also fit their needs.

- Three metric tons of plutonium residue (defined as waste that contains greater than $1 \%$ plutonium by weight) is currently contained in 3,500 55-gal drums. At least $60 \%$ of this plutonium residue is in a salt form that is highly corrosive. In August 1994, Rocky Flats received an unsolicited proposal from UltraTech International, Inc., which stated that their packaging concept may be able to satisfy Rocky Flats needs, if Rocky Flats could provide the funding for additional testing. Due to budget constraints, Rocky Flats was unable to proceed with the 
proposal, even though they think that there is a significant need for packaging of this type. After the meeting, Rocky Flats provided a copy of the UltraTech proposal to WHC and requested WHC or DOE assistance to procure some of these packagings for further testing. However, WHC was unable to assist Rocky Flats at this time.

- A large quantity of uranium waste of various enrichment levels is stored onsite. Some of this waste is also in metal form. All of this material will eventually need packaging for transportation and disposal.

- A large amount of waste that has been classified as hazardous under the RCRA is stored onsite. A large amount of the waste has come from digging up the first nine to $12 \mathrm{~m}$ ( 30 to $40 \mathrm{ft}$ ) of soil from the side of a hill on the Rocky Flats site. This soil is contaminated with oils, carbon tetrachloride, and polychlorinated biphenyls (PCBs). Some of this waste is also classified as low-level radioactive waste, making it a mixed waste. The mixed waste will be packaged for shipment to the EnviroCare of Utah mixed waste disposal site. The EnviroCare site will directly bury the low-level mixed waste, so EnviroCare has requested that the waste be shipped to them in gondola-type railcars (it is not clear that this will satisfy DOT requirements).

- A large amount of radioactive waste, including some transuranic (TRU) waste, to result from the decontamination and decommissioning of their site buildings is expected. Most of this waste will be in concrete or metal form.

- 200 crates containing asphalt and soil that is a mixed waste. These crates will be shipped to EnviroCare of Utah for disposal if they can be shown to meet DOT regulations and will be accepted by the disposal site.

\subsubsection{Rocky Flats Packaging Issues}

The following packaging-related issues were also raised by Rocky Flats.

- Rocky Flats stated that several Type B weapons packagings that have had certifications recently expire could be used to meet some of their packaging needs. However, the certifications of these weapons packagings were issued by the DOE Albuquerque Office, and are unlikely to be renewed without major upgrades to the packagings, since most will not meet all current regulatory requirements. WHC has ordered a listing of all of the weapons Certificates of Compliance from the DOE Albuquerque Office to see whether any of these packagings could be used or modified to meet current needs with a minimum of effort. 
- Rocky Flats expressed interest in the Type B Drum and the Multipurpose Explosives currently under development by DOE. Rocky Flats stated that they would use the Type B Drum for disposal of some TRU waste if it is acceptable for use at WIPP. They also requested information on the Multipurpose Explosives packaging program, which was sent to them.

\subsection{SAVANNAH RIVER SITE}

\subsubsection{Savannah River Packaging Development}

Savannah River has an 11 person packaging group with ready access to more resources, such as analysis, testing, and fabrication facilities, as needed. The bulk of Savannah River's packaging work is focused on meeting offsite transportation needs. Savannah River is currently reviewing all Safety Analysis Reports for Packagings (SARPs) for their onsite packagings to determine whether those SARPs meet current standards. Savannah River has certified nine Type B packagings for offsite use and are currently going through the DOE certification process for four more packagings. The certified packagings, which have been certified by either DOE-HQ or DOE-Albuquerque, are for shipment of plutonium, tritium, or weapons components. The four packagings currently undergoing the certification process will be used for the shipment of plutonium, in either oxide or metal form. Savannah River has also developed several Type A packagings, including a packaging for shipment of 15 one liter liquid samples.

\subsubsection{Savannah River Packaging Needs}

The packaging needs listed below were identified by Savannah River and include general DOE packaging needs that Savannah River has identified during interactions with other sites.

- A need for Type B bulk tritium packaging exists at the site. The current packagings being used, the UC-609 and the LP-50, are over 20 year old designs that have had their approved contents reduced in order to stay current with changing regulations. The current certification of the UC-609 expires in 1998, while the LP-50 is in the DOE recertification process. There is uncertainty in future certificate renewals. Therefore, a packaging development program should be started soon to ensure that packagings for the bulk shipment of tritium exist when those certifications expire.

- The DOE certification process is underway (with Lawrence Livermore National Laboratory's SARP review group) for four plutonium packagings (9972, 9973, 9974, and 9975) that upgrade four existing plutonium packagings (9965, 9966, 9967, and 9968). The 9965-9968 family is being upgraded (to the $9972-9975$ family) to Type $B(U)$ or $B(M)$ packagings to allow further fabrication and 
international use. The SARPs for the new packagings are based on the results of extensive testing and analysis to verify that the packagings meet NRC requirements. All of these packagings use cane fiberboard (also known by the brand name of Celotex) for insulation. The primary use for Celotex is as a roofing material and it is manufactured to meet building material standards. As a result, the detailed database of Celotex material properties, such as shock resistance and aging effects, are not well quantified, but were adequate, since the packagings passed all required tests. However, during the ongoing packaging certification process, the SARP review group has inquired into those properties. Because Celotex is also used in several other radioactive materials packagings, Savannah River believes further testing is required to quantify the properties.

- A need for an all-welded primary containment vessel that will fit inside of the 9975 packaging exists. Savannah River stated that, once the 9975 packaging is certified for use, they will obtain an amendment to the SARP that will permit use of an all-welded primary vessel inside of the 9975 container. Because the plutonium is expected to go into long-term storage before final disposition, an all-welded primary containment vessel will prevent repackaging of the plutonium before shipment.

- An onsite packaging need for a family of tubes that could be used for onsite shipment and disposal (at the Savannah River burial site) of pumps and hardware used in high-level liquid waste storage tanks exists. These packagings may need to meet Type A packaging standards. Since Hanford has already began development of similar packagings for pumps for their high level liquid waste tanks, Savannah River was put into contact with Hanford personnel to determine whether they could use the Hanford-developed packagings. At this time, it is not clear whether Savannah River can use the Hanford packagings.

- There is a need to develop a new cask that provides shielding for onsite transportation of tritium spent melts. The spent melt is located inside of a $46 \mathrm{~cm}$

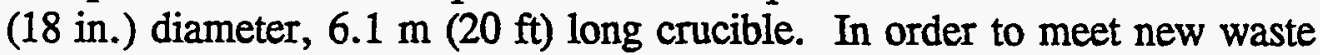
management guidelines, that crucible is now required to be enclosed in an overpack that provides containment. However, the existing onsite transportation cask for the crucible, which provided shielding for transportation, does not have enough clearance to fit the overpack. Therefore, a new cask that meets current onsite packaging requirements needs to be designed to fit the overpack.

- There is a disposal need for highly-activated ion exchange resin that is left over from plutonium production activities. This resin needs a disposal packaging that can be used for onsite transportation to the burial site. Hanford also has the same need. 
- There is an interest in using the chilled liquid sample container that is under development by Oak Ridge to support their environmental restoration activities. Once Oak Ridge has a packaging available, Savannah River will also use the packaging.

- Type A quantities of highly-activated liquid samples (less than $125 \mathrm{~mL}$ per sample) are currently shipped onsite in a depleted uranium container known as the doorstop. The doorstop has a $15 \mathrm{~cm}$ (6 in.) diameter, is about $25 \mathrm{~cm}$ (10 in.) tall, and weighs about $55 \mathrm{~kg}(120 \mathrm{lb})$. Savannah River is planning to develop a certified Type A packaging that could encase the doorstop container without modifying it. Occasionally, the samples are Type B quantities, but can be diluted to Type A amounts if necessary.

- Spent nuclear fuel from many different sources, including their own plutonium production reactors and foreign research reactors is stored at Savannah River. Because of nuclear proliferation concerns, DOE is currently retrieving spent nuclear fuel that was loaned to foreign countries for research purposes several decades ago. Therefore; the stockpile of spent nuclear fuel at Savannah River will continue to grow over the next several years. When final disposition for this fuel is determined, packaging to support that disposition will need to be identified.

\subsubsection{Savannah River Packaging Issues}

The items listed below are either recommendations made by Savannah River to improve packaging efficiency across the DOE Complex or solutions that they have developed for some of their packaging needs.

- HEUN will eventually be shipped to Oak Ridge for processing. At present, Savannah River intends to dilute the HEUN to a $10 \%$ concentration and ship it to Oak Ridge as low specific activity material, since they cannot ship the HEUN without diluting it, due to criticality concerns.

- A contract basis for purchasing packaging across the DOE Complex would help eliminate situations where different facilities obtain identical packagings from the same vendor for different prices. The contract basis for purchasing packaging would also help standardize packagings.

- It would be more cost effective if the DOE had a central location for reconditioning reusable packagings. Currently, each DOE site has its own contract with a packaging reconditioning facility. Centralizing the reconditioning activity into a single DOE Complex contract would greatly reduce costs. 


\section{DOE/RL-95-43 REV 0}

- A French LR-56 liquid packaging is being purchased by Savannah River. The LR-56 is an internationally-certified Type B container with a 4,000 L (1,057 gal) capacity. However, the LR-56 is not certified for Type B use in the United States. The LR-56 may be used for onsite Type B shipments or for offsite Type A shipments. Savannah River is planning to use the LR-56 to replace their onsite Type B liquid packaging that has a $19,000 \mathrm{~L}$ ( 5,000 gal) capacity, but is 20 years old. Hanford and Oak Ridge are also purchasing their own LR-56s Hanford for onsite Type B use and Oak Ridge for Type A liquid shipments.

\subsection{OAK RIGE NATIONAL ENGINEERING LABORATORY}

\subsubsection{Oak Ridge Packaging Development}

Oak Ridge is split into several different sites, $\mathrm{X}-10, \mathrm{~K}-25$, and $\mathrm{Y}-12$, each of which has its own transportation and packaging group. These sites also have their own waste management groups, and the site contractor, Martin Marietta, is responsible for waste management at the Portsmouth, $\mathrm{OH}$, and Paducah, $\mathrm{KY}$, facilities. Ongoing packaging development activities that were discussed at this meeting include development of a chilled liquid sample container that can be used with nonradioactive, hazardous environmental samples and maintain a temperature of $4^{\circ} \mathrm{C}$ for 48 hours, possible purchase of a Type A Sea-Land container that has been developed by Croft Associates, and modification of a GE-2000 cask to allow shipment of high-flux intensity reactor spent fuel to a storage site possibly Savannah River - once the moratorium on DOE spent fuel shipments is lifted. The Y-12 plant has developed many packagings for the DOE Office of Defense Programs and is currently completing the certification process on the $\mathrm{DC}-1$ (double containment) packaging for highly-enriched uranium.

\subsubsection{Oak Ridge Packaging Needs}

The packaging needs identified by Oak Ridge are listed below. Oak Ridge stated that they were not able to obtain information from waste management personnel at the five sites managed by Martin Marietta or from personnel performing energy research at the site, and none of those personnel attended this meeting. Therefore, all packaging needs that exist at Oak Ridge may not be identified.

- A large amount of onsite liquid waste eventually will need to be either processed or disposed. Some of this liquid waste is also corrosive. At present, no packagings exist in the DOE Complex and no packaging developments are underway for transportation of greater than a few Ls of Type A or B liquids. 
Oak Ridge will eventually need to ship Type A, and possibly Type B liquids in 55-gal drums or larger containers in order to economically perform these transfers.

- In order to assist with waste management and environmental remediation activities, Oak Ridge has a need for Type A and B sample kits. These sample kits could be used to ship both liquid and solid samples and have a capacity of one liter. At present, as part of the Pond Waste Project, Oak Ridge is only shipping radioactive liquids that are limited quantities or low specific activity. However, once hot cell remediation begins, Oak Ridge will need to ship Type A liquid samples, and possibly Type B liquid samples. Oak Ridge believes that a commercial vendor's ongoing Type A liquid sample packaging development may be able to satisfy their needs.

- Certified packagings for several strong neutron sources $\left({ }^{252} \mathrm{Cf}\right)$ will expire in 1996. These packagings are large concrete and lead packages $-11,400 \mathrm{~kg}$ and $22,700 \mathrm{~kg}(25,000 \mathrm{lb}$ and $50,000 \mathrm{lb})$ - that cannot be easily handled. In fact, a few vendors have expressed an interest in using these sources, but have been unable to, as a result of the handling problems associated with such heavy casks. Oak Ridge is considering developing a new, smaller cask because they do not know whether the existing cask certifications will be renewed. The smaller cask would use lightweight, neutron absorbent materials for shielding, so vendors that do not have heavy equipment can handle the cask and use the sources. Because Oak Ridge is not aware of any casks that have used lightweight, neutron absorbent materials, some research will need to be done.

- A large number of environmental sample shipments to offsite facilities for analysis is currently occurring. Oak Ridge is considering the development of a mobile laboratory facility that can travel to the sampling site, or within facility boundaries, to greatly reduce the cost and number of shipments that have to comply with DOT regulations. Building a central laboratory facility at Oak Ridge would still require a large number of DOT-compliant shipments from the other sites that do not have the laboratory because Oak Ridge does not invoke onsite controls for interfacility shipments and makes all of those transfers in full compliance with offsite DOT regulations.

\subsubsection{Oak Ridge Packaging Issues}

The packaging issues identified by Oak Ridge are listed below. Once again, all issues that exist at Oak Ridge may not be listed below.

- Because all transfers between sites are in full compliance with offsite DOT regulations, Oak Ridge is very concerned about the impact of DOT Docket HM-169A, Transportation Regulations; Compatibility with Regulations of the International Atomic Energy Agency; Notice of Proposed Rule (DOT 1989), if it 
is implemented in the form originally proposed by the NRC and DOT in 1988 and 1989. As originally written, Docket HM-169A would limit the amount of radioactivity that can be shipped as low specific activity in exclusive-use vehicles with strong, tight packaging to twice the $A_{1}$ or $A_{2}$ value, and would instead require packaging that has passed specific performance testing. All lifting devices on this performance tested packaging will be required to support the entire weight of the container. Oak Ridge has $14,0001.2 \mathrm{~m} \times 1.2 \mathrm{~m} \times 1.8 \mathrm{~m}$ (4 $\mathrm{ft} \times 4 \mathrm{ft} \times 6 \mathrm{ft}$ ) ST-5 steel boxes that were made by the K-25 facility years ago and are used for routine low specific activity shipments between the sites. The ST-5 boxes have lifting devices on the lids that can only be used to lift the lid and not the entire package. With implementation of HM-169A, Oak Ridge would no longer be able to use these containers and would have to purchase new containers or modify the existing ST-5 boxes.

- To simplify and reduce the cost of DOE Complex packaging development activities it was suggested that the waste acceptance criteria and the development of low specific activity waste boxes should be standardized and that all packaging developed for DOE use can either be reused or buried, depending on its intended application.

\subsection{IDAHO NATIONAL ENGINEERING LABORATORY}

\subsubsection{Idaho National Engineering Laboratory Packaging Development}

Idaho National Engineering Laboratory (INEL) personnel identified one packaging development that had recently been completed and one ongoing effort. INEL will soon make a Type B shipment of ${ }^{241} \mathrm{Am}$ sources inside of a DOT Specification $6 \mathrm{M}$ container. INEL is presently amending the SARP for the Chem-Nuclear 1-13C cask to allow shipments that contain 55-gal drums filled with Type B quantities of unsealed low-level radioactive waste, since those inner packagings are loaded underwater and need an opening to drain all water before shipment. INEL is also developing a shielded transfer system that can remotely place the drums inside of a vault where they will be loaded into the Chem-Nuclear 1-13C cask. The Advanced Test Reactor Isotope Program has been using a small Type B shipping container with an inner cavity $5 \mathrm{~cm}(2 \mathrm{in}$.) long and $1 \mathrm{~cm}(.5 \mathrm{in}$.) in diameter for the shipment of $\mathrm{Ir}^{192}$ sources. Currently, the Advance Test Reactor Isotope Program uses the GE-8500 cask, which they have certified as a Type A packaging, inside of a DOT Specification 20WC overpack, which qualifies as a Type B packaging under the DOT regulations. 


\subsubsection{Idaho National Engineering Laboratory Packaging Needs}

The Needs Assessment visit was one of the first opportunities for packaging personnel from the different facilities on the INEL site to discuss their packaging needs. The packaging needs identified by INEL facilities include the following.

- As part of a program to characterize TRU waste from abandoned hot cells, INEL needs a packaging for chilled shipments of Type B quantities of TRU samples (containing plutonium and americium) that also contain hazardous constituents, which require characterization. These samples will need to be transported to offsite laboratories for analysis. The initial samples from these hot cells had low levels of radioactivity and shipment was not difficult, but as this packaging continues, the need will emerge. INEL stated that their informal discussions with other DOE facilities have shown this need to be widespread.

- Argonne-West stated that they have TRU waste in large boxes that, at present, cannot be shipped to its final disposal site (most likely WIPP) in the TRUPACT-II container. The radiation level exceeds the limits for the TRUPACT-II. Argonne-West is also concerned that this TRU waste may not meet the waste acceptance criteria of the Radioactive Waste Management Complex, which will be the TRU waste consolidation point on the INEL site and will require Argonne-West to store the waste onsite until acceptable packaging is developed. Storing the TRU waste onsite will require changes to the RCRA permit for the Argonne-West facility.

- The chilled liquid packagings that are under development or are being coordinated by Oak Ridge are of interest. INEL needs packaging that meets all DOT requirement for shipping environmental samples to analysis laboratories. They also indicated that they may be interested in onsite use of the French LR-56 container, which is being procured for onsite use at Hanford. INEL personnel were given the name of the lead engineer at Hanford to contact to obtain additional information on that container.

- A GE-2000 cask for shipment of spent nuclear fuel and low-level radioactive waste is needed. They are currently using the BMI-1 cask, but its certification expires in May 1995 and may not be renewed. INEL stated that they were attempting to purchase a GE-2000 cask in conjunction with Oak Ridge so both facilities could use the cask; although, Oak Ridge purchased a GE-2000 without input from INEL. Therefore, depending on the availability of funding, INEL may have to purchase their own GE-2000 cask.

- There is a large amount of slightly contaminated metal that they would like to recycle into shipping containers instead of disposing. Not all of this material can be disposed, due to burial site restrictions (i.e., contaminated lead cannot be 
disposed of at this time). INEL stated that they have large inventories of contaminated stainless steel and lead that could be recycled and were interested in the using the metal for shipping containers.

\subsubsection{INEL Packaging Issues}

The following items were identified by personnel from INEL as areas that are significant issues with regard to current policies or future regulatory changes.

- INEL has $11,0001.2 \mathrm{~m} \times 1.2 \mathrm{~m} \times 2.4 \mathrm{~m} \mathrm{(4ft \times} 4 \mathrm{ft} \times 8 \mathrm{ft})$ boxes of waste that will eventually need to be buried. Approximately $60 \%$ of this waste is TRU waste, while the other $40 \%$ is low level radioactive waste. The boxes are manufactured out of various materials such as wood and steel and contain Type B quantities of material. The current WIPP waste acceptance criteria will require repackaging of the TRU waste into 55-gal drums or Standard Waste Boxes that can be shipped inside of the TRUPACT-II container. INEL would prefer to develop a Type B overpack (or use an existing container) for these boxes to prevent repackaging this large volume of waste, but if the WIPP waste acceptance criteria is not changed, repackaging will be required.

- The Chemical Processing Plant at INEL has a Super Tiger container (NRC Certificate of Compliance number 6400) that is a Type B packaging with exterior dimensions of $2.4 \mathrm{~m} \mathrm{x} 2.4 \mathrm{~m} \mathrm{x} 6.1 \mathrm{~m}(8 \mathrm{ft} \times 8 \mathrm{ft} \times 20 \mathrm{ft})$. The Super Tiger has an internal cavity of $1.93 \mathrm{~m} \times 1.93 \mathrm{~m} \mathrm{x} 4.37 \mathrm{~m}$ (76 in. $\times 76$ in. $\times 172$ in.) with a wide variety of allowable contents. This container is available for use throughout the DOE Complex.

- INEL is concerned that it may be difficult to procure drums that meet Type A standards now that the POP regulations have eliminated DOT Specification packaging. The DOE Type A testing program had conducted testing of DOT Specification packagings, so any DOE user could be assured that when they purchased a tested DOT Specification drum, they were purchasing a Type A packaging. Now that DOT Specification packagings no longer exist, it will be more difficult to ensure that procured POP packagings, such as drums, also meet Type A requirements.

- INEL is very interested in coordination of packaging activities across the DOE Complex. For example, INEL would like a centralized listing of packagings that are only used for onsite shipments of radioactive material since several DOE sites such as INEL, Savannah River, and Hanford make many onsite shipments, which only meet onsite requirements that are not as stringent as NRC requirements. Currently, no centralized listing of such packagings exists, so several sites may be concurrently developing packagings for similar uses or may be developing packaging that already exists at other sites. Similarly, INEL 
would like to ensure that development of packaging for offsite use is also coordinated across the DOE Complex to eliminate duplication of effort. Finally, INEL suggested circulation of a DOE Complex newsletter that would list the packaging needs of all DOE sites, so sites that have already solved similar issues could assist other sites.

\subsection{PANTEX PLANT}

\subsubsection{Pantex Plant Packaging Development}

The packaging developments performed in the past and currently underway at the Pantex Plant have been almost exclusively used for the nuclear weapons program. At present, Pantex has been tasked by the Nuclear Explosives Safety Division of DOE-Albuquerque to keep the certification of the MH-2800 and the FL containers current and to develop an onsite storage container (known as the AT-400A) for plutonium pits. The AT-400A is being jointly developed by Pantex, Lawrence Livermore, and Sandia, and may be ready for use as soon as December 1995. The AT-400A will eventually also be certified as a Type B packaging so some pits can be shipped to laboratories for analysis. Pantex has also been trying to identify alternate uses for the AL-R8 container, which will be gradually replaced by the AT-400A, but could still be used as a Type A container by other facilities.

\subsubsection{Pantex Plant Packaging Needs}

Pantex was very interested in coordinating their needs, which are listed below, across the DOE Complex so that other sites that have similar needs can coordinate any necessary packaging development so that as many needs as possible are satisfied with each packaging development.

- All radioactive waste generated by the Pantex Plant are currently shipped to the Nevada Test Site burial grounds for disposal. Most of the waste is packaged in metal H-744 boxes, which have dimensions of $2.1 \mathrm{~m} \mathrm{x} 1.2 \mathrm{~m} \mathrm{x} 1.2 \mathrm{~m} \mathrm{(7ft} \mathrm{x} 4 \mathrm{ft}$ $\mathrm{x} 4 \mathrm{ft}$ ), are strong, tight containers, and are capable of withstanding an internal pressure of $192 \mathrm{kPa}(4,000 \mathrm{lb} / \mathrm{sq} \mathrm{ft})$, which meets the Nevada Test Site waste acceptance criteria. Pantex is interested in development of different sizes of metal packagings that meet all requirements of the Nevada Test Site. waste acceptance criteria and are more cost-effective than the H-744 box. Pantex has been working with Galbreath Containers, who manufactures the $\mathrm{H}-744$ box, to develop these new packaging shapes. 
- Two quarter-sized sources reading $200 \mathrm{rem} / \mathrm{hr}$ on contact need to be shipped to the Nevada Test Site burial ground for disposal. Pantex is interested in placing these sources inside of a 30-gal drum that has adequate shielding for the high radiation levels. These containers would be one-time use packagings and only need to satisfy Type A standards.

- A POP is needed that can be used to ship explosives that were previously shipped in DOT Specification packaging. Pantex is very interested in the Multipurpose Explosive packaging and intends to use the Multipurpose Explosive packagings once they are available.

- As a result of disassembling old nuclear weapons that no longer have packaging for the components readily available, Pantex needs to locate and stockpile as many old weapons component containers as possible. Pantex will use these old containers for onsite storage of these components. In late 1994, Pantex tried to acquire some component packaging that had been in long-term storage at Mound Laboratory. However, before Pantex was able to acquire those packagings, the Mound DOE office directed Mound to dispose of the containers, which was completed. Pantex would like to prevent such occurrences in the future.

- Packaging that can be used for onsite storage of special nuclear material resulting from the disassembly of nuclear weapons is needed. At the request of the Nuclear Explosives Safety Division, Pantex is developing a packaging that will meet this need.

\subsubsection{Pantex Plant Packaging Issues}

Most of the issues raised by the Pantex Plant centered on their preference for centralizing packaging development activities across the DOE Complex. The issues raised by Pantex are as follows:

- Before packaging vendors can be used, a Quality Assurance evaluation of the vendor's facilities has to be performed. Pantex stated that there have been instances where their Quality Assurance representatives visit a vendor for a week-long evaluation one week, while one or two weeks later another DOE facility's Quality Assurance representatives visit the same vendor. Pantex stated that they have started to use some vendor evaluations from the Supplier Quality Information Group (SQIG), but that there is no DOE requirement to do so. Pantex recommended that a greater emphasis be placed on coordination of Quality Assurance reviews of vendors through the SQIG program. 
- The status of the Low-Level Waste Container Standardization Group. Pantex was informed that, to WHC knowledge, no container standardization activity has occurred since August 1994. Pantex stated that they thought the standardization of low-level waste packaging across the DOE Complex was great potential cost savings.

- Their support for the Packaging Council that was tentatively established at a November 1994 meeting at Oak Ridge National Laboratory was noted. Pantex stated that such a Packaging Council could eliminate a majority of the duplication of effort within the DOE Complex, improve communication, and prevent occurrences such as Mound Laboratory disposing of containers that were needed at Pantex (see Section 3.6.2).

- The development of a centralized DOE-sponsored POP testing program (similar to the existing Type A testing program) would be cost-effective. Performing all POP testing for the DOE through one testing facility and coordinating that testing would reduce duplication of POP development effort and would most likely result in lower costs for each individual test, as opposed to each facility establishing separate contracts with a wide variety of test facilities.

- High explosive-contaminated soil samples are being shipped to commercial laboratories for analysis. The high explosive residue is left over from World War II activities at the site. The soil contains approximately $50 \mathrm{ppm}$ of the high explosive and therefore is not an explosion hazard. Pantex has been performing testing of the samples to show that the samples are not explosive before shipment to the laboratories. If a sample was explosive, Pantex would ship the sample inside of the pipe container (DOT Exemption 8451).

\subsection{LOS ALAMOS NATIONAL LABORATORY}

\subsubsection{Los Alamos Packaging Development}

Los Alamos National Laboratory is currently attempting to certify the Croft Associates' SAFEKEG packaging as a Type B so they can be used for air transport of plutonium. This packaging is currently certified for use internationally, but the review has not been approved for use in the United States. The SAFEKEG SARP is currently under review by Argonne National Laboratory on behalf of DOE EH-32, but the review has been suspended due to lack of funding. Los Alamos has also designed the Nevada Test Site-Mixed Fission Product Sample Shipper, which, once approved, can ship up to $4.5 \mathrm{I}$ of Type B liquid. The Nevada Test Site-mixed fission product container would provide $5.0 \mathrm{~cm}(2$ in.) of tungsten shielding. Neither Type A or Type B certification for the Nevada Test Site-Mixed Fission Product container is being pursued at this time due to a lack of funding. Los Alamos stated 
that it would cost $\$ 60,000$ to obtain a Type A certification for the Nevada Test Site-Mixed Fission Product packaging. The cost to obtain a Type B certification for the Nevada Test Site-Mixed packaging would be significantly higher.

\subsubsection{Los Alamos Packaging Needs}

The following packaging needs were identified by Los Alamos in the meeting and in Los Alamos National Laboratory letter BUS-6:95-129 (LANL 1994).

- A critical need for economical, easy-to-use, single trip Type A containers that can ship up to $500 \mathrm{~mL}$ of liquid exists. These containers must be able to ship a variety of laboratory type bottles (e.g., poly, glass, square, and round). The 3M SafeSend ${ }^{\text {mx }}$ Model IS-500ML Infectious Substance Shipping System may be able to meet this need.

- A reusable, one liter volume, Type A liquid packaging is also needed. Since Los Alamos does not have such a container, every time that a Type A liquid shipment is made, the onsite requirements have to be invoked (most shipments are two-way). Making an onsite shipment at Los Alamos requires use of the police force to restrict public access to the highways the shipment is travelling on and costs approximately $\$ 5,000$ per road closure. The Hedgehog, which was recently certified as a Type A liquid packaging by WHC, should satisfy this need.

- The 2799E/H container for shipments of liquid plutonium samples that require an International Atomic Energy Agency safeguards surveillance program is needed. Since no certified packaging currently exists for Type B quantities of liquid plutonium, expensive road closures are required for these onsite liquid plutonium shipments. Due to the road closure costs, Los Alamos stated that they have not been able to obtain funding for these onsite shipments without use of the 2799E/H. Los Alamos stated that New Brunswick Laboratory is also interested in the use of the $2799 \mathrm{E} / \mathrm{H}$ container for liquid plutonium shipments.

- A packaging is needed to replace the B-3 container, which has a cavity $67.3 \mathrm{~cm}$ (27 in.) in diameter and is $109.9 \mathrm{~cm}$ (43.3 in.) high with a minimum of $15.2 \mathrm{~cm}$ (6 in.) of lead shielding. The B-3 is a DOE-certified Type B packaging that can no longer be fabricated and has its certification expire in December 1995. Los Alamos currently uses the B-3 for high level radioactive waste shipments of Type $B$ quantities of activation and mixed fission products. Los Alamos states that it is not certain that its certification will be renewed in December, and a need exists for a similar packaging design in the future, even if the certification is renewed beyond the end of this year. 
- Type B packaging that can ship high-level liquid waste is also needed. This container would be used to ship waste to the analytical laboratories at Los Alamos from other DOE facilities (e.g., Hanford tank waste). The PAS-1 cask amendment that has been developed by WHC may be able to meet this need.

- There is a DOE Complex need for a heavily shielded Type B container that can be used to ship irradiated targets from accelerator laboratories. Since the DOE performs a wide variety of research and development activities that result in one-of-a-kind targets, this packaging would have to accommodate a wide variety of target configurations. The main requirement is that this packaging provide a large amount of gamma shielding because criticality is a much lesser concern for these targets.

\subsubsection{Los Alamos Packaging Issues}

The following are the packaging issues identified by Los Alamos in the meeting and in their letter (LANL 1994).

- There is a concern that the elimination of DOT Specification packagings could severely impact the ability of DOE sites to procure packagings that are certified as Type A packagings in WHC-EP-0558, Test and Evaluation Document for DOT Specification 7A Type A Packaging (WHC 1994). In order to be cost-effective, Los Alamos is interested in a centralized DOE identification and qualification of specific packagings and vendors that are acceptable for use in place of the now extinct DOT Specification packagings. A centralized DOE effort would eliminate the redundancy of having each DOE facility perform their own evaluation of the same vendors and packagings.

- The centralization of the Quality Assurance certification of packaging vendors, through a program such as SQIG, interested Los Alamos. The concerns identified by Pantex in Section 3.6.3 are shared.

- The POP and Type A packaging should be stocked and retailed through the General Services Administration, similar to the way other government items are handled. Los Alamos stated that using the General Services Administration to buy all POP and Type A packaging instead of having each individual DOE site purchase their own packaging would reduce the cost of the packaging due to large volume discounts, decrease DOE needs for storage and warehousing, and reduce overhead for packaging purchases.

- Blanket DOE approval for the use of different configurations of the $6 \mathrm{M}$ container is desirable. Los Alamos suggests using three or four standard configurations that could accommodate all radioactive material that could be packaged and shipped. An example of separate approvals for plutonium oxide, plutonium metal, and other radionuclides authorized by DOT was provided. 
- Existing inventories of Type A and Type B packagings at DOE sites that are no longer used by the sites that own the packagings should be assessed, controlled, and ultimately redistributed throughout the DOE, instead of just being disposed. The Packaging Management Tracking System under development by DOE-HQ may be able to assist with this task once it is completed, but some action should be taken now, before a large amount of the existing inventory is lost.

\subsection{LAWRENCE LIVERMORE NATIONAL LABORATORY}

\subsubsection{Lawrence Livermore National Laboratory Packaging Development}

Lawrence Livermore National Laboratory (LLNL) identified that they are currently developing the following packagings.

- The site has uranium trimmings that are suspended in mineral oil that will need to be shipped for disposal in either 30- or 55-gal drums. LLNL is in the process of developing packaging for this waste. The waste itself meets the standards for low specific activity material, but since this waste is not expected to be shipped via an exclusive use vehicle, the packaging will have to meet Type A criteria. LLNL expects to open a docket for testing through the DOE EH-32 Type A testing program before the end of FY 1995.

- In coordination with a commercial vendor, LLNL is developing nonradioactive hazardous materials packagings for $20250 \mathrm{~mL}$ bottles and $12500 \mathrm{~mL}$ bottles. These packagings will be able to ship chilled samples. Each bottle will fit inside of a sleeve that will enable the packaging to meet all air transportation requirements. LLNL may also need to use these packagings for chilled Type A shipments. LLNL expects these packagings to be available by mid-Spring and will share the information about these packagings with WHC as soon as they become available, so WHC can discuss the packagings as part of the Needs Assessment.

\subsubsection{Lawrence Livermore Packaging Needs}

LLNL identified the following packaging needs.

- Since they have no POP packaging development program for explosives, LLNL believes that the Multipurpose Explosive packaging program is essential for them to continue shipping explosives and thus a POP for explosives is needed to conform to the POP regulations that take effect in October 1996.

- A Type B packaging that can be used to overpack 55-gal drums that contain metal and debris with tritium contamination. The existing UC-609 containers do 
not have adequate volume to ship 55-gal drums, so this waste would have to be repackaged to use the UC- 609 containers. If possible, LLNL prefers to avoid repackaging this waste. LLNL was informed of some Type A packagings that can be used with tritium waste, but these containers are unlikely to be used with this Type B waste.

- LLNL is interested in a Type B packaging that can ship TRU contaminated mixed fission product waste or plutonium oxide waste that is larger than the 9965 or 9968 packagings that were developed by Savannah River and the $9972-9975$ containers that are under development by Savannah River.

- Since the DOE certification for the Super Tiger container (see Section 3.5.3) expired several years ago, no container exists that can ship very large volumes of Type B waste. LLNL has a need to ship large boxes, approximately $1.2 \mathrm{~m} \mathrm{x}$ $1.2 \mathrm{~m} \times 2.1 \mathrm{~m}(4 \mathrm{ft} \times 4 \mathrm{ft} \times 7 \mathrm{ft}$ ), for burial. This waste includes gloveboxes with residual plutonium contamination. After the meeting, WHC contacted personnel at INEL that have a Super Tiger container. The Super Tiger at INEL is owned by LLNL and still has a current NRC Certificate of Compliance (Number 6400). However, the LLNL waste is not approved for use with the Super Tiger, so LLNL will still need a new packaging, since the NRC is unlikely to approve an amendment to the Certificate of Compliance for a package that can no longer be manufactured.

- Historical soil samples in 5-gal cans at Site 300 will need to be shipped to their main facility for storage. LLNL prefers to keep this waste together, but in order to.ship it as a Type A material, they can only ship one pound $(0.5 \mathrm{~kg})$ at a time.

\subsubsection{Lawrence Livermore Packaging Issues}

LLNL is concerned that the existing Type A certification for now defunct DOT Specification packagings (such as DOT Specification $17 \mathrm{C}$ and $17 \mathrm{H}$ drums), may not be easily transitioned to the new Performance Oriented Packaging requirements. LLNL feels that DOE-HQ should address this issue before October 1996, when use of Specification packaging becomes prohibited.

\subsection{SANDIA NATIONAL LABORATORY - LIVERMORE}

\subsubsection{Sandia-Livermore Packaging Activities}

The bulk of Sandia-Livermore's experience with packaging design has been for classified weapons components. Sandia-Livermore continues to do packaging work for the Nuclear Explosives Safety Division of DOE-Albuquerque. Sandia-Livermore has also been performing a study of packaging alternatives for surplus fissile materials disposition for the 
DOE Office of Fissile Materials Disposition (MD-1). As part of their study, SandiaLivermore has been compiling a listing of existing packagings for plutonium and determining whether additional packagings for plutonium will need to be developed.

\subsubsection{Sandia-Livermore Packaging Needs}

The items listed below are Sandia-Livermore packaging needs. The explosives packagings are needed by Sandia-Livermore for their own use, while the other packagings listed are DOE Complex needs for the Weapons Dismantlement Program.

- The Multipurpose Explosive packaging program is required to continue shipping explosives. If the Multipurpose Explosive packaging program is cancelled again, Sandia-Livermore feels that they will have to suspend all transportation of explosives until an alternative packaging is developed. Sandia-Livermore knows of no other existing packaging or packaging under development that could be used with their explosives.

- Old explosives that have not been classified in accordance with current DOT regulations will eventually need to be disposed. These explosives (fire sets) are up to $46 \mathrm{~cm}$ (18 in.) in diameter and $15 \mathrm{~cm}(6 \mathrm{in}$.) tall and contain up to 10 grams of high explosives. It is unclear whether Multipurpose Explosive packagings can be used with these explosives.

- Determining alternatives for shipping $\mathbf{5 0}$ metric tons of plutonium metal to a yet to be determined Defense Programs site for storage, processing, and/or disposal is in process. This material has recently been classified as excess by DOE-HQ. Followup conversations with Sandia-Livermore indicate that this plutonium will most likely be poisoned and converted into ceramic pellets for disposal. The DOT $6 \mathrm{M}-2 \mathrm{R}$ packaging may be able to be used to meet this need, but is probably too small to be able to economically dispose of this waste, so a new packaging will need to be designed. The Type B Drum concept may meet this need.

- Large items such as high efficiency particulate (HEPA) filters and crucibles contaminated with more than 20 curies of plutonium will need shipping and disposal containers that offer double containment. These types of items have never been disposed of before, because the plutonium was extracted from these items and reprocessed. 


\subsection{LAWRENCE BERKELEY LABORATORY}

\subsubsection{Lawrence Berkeley Packaging Needs}

Lawrence Berkeley does not have a large, dedicated transportation and packaging staff to develop containers to meet their packaging needs; therefore, Lawrence Berkeley is dependent on commercially available products and other DOE facilities. The packaging needs identified by Lawrence Berkeley are listed below.

- A large amount of tritium contaminated waste is disposed of with the Enduropak packaging, since the Enduropak is a Type A packaging certified by the manufacturer to be able to contain tritium. Lawrence Berkeley was interested in alternatives to the Enduropak which were more cost-effective. Lawrence Berkeley was informed of upcoming changes to the tritium waste packaging developed by Princeton Plasma Physics Laboratory, which may make it more useful to the DOE Complex and a possible alternative to the Enduropak. The only other possible packaging is the UC-609 container, which is certified as a Type B packaging, but cannot be used for disposal.

- There are approximately 100 sources created by their accelerator that will need to be disposed of at the WHC burial site. Some of these sources have been stored at Lawrence Berkeley in their Pit Room for at least 35 years. Most of the sources are no more than a few centimeters tall and do not require shielding. Lawrence Berkeley is interested in a packaging for these sources that would meet both transportation and disposal requirements. The 3M SafeSend ${ }^{\text {Tx }}$ packaging may meet this need, if it can be shown to meet burial site requirements.

- Three irradiators that contain Type B sources need to be disposed. The irradiators are as large as $1.5 \mathrm{~m} \mathrm{x} 1.8 \mathrm{~m} \mathrm{x} 2.7 \mathrm{~m}(5 \mathrm{ft} \times 6 \mathrm{ft} \times 9 \mathrm{ft})$, but the sources themselves are no larger than a few centimeters in diameter. The sources could be removed from the irradiators and disposed of separately, but would require a large amount of shielding. Lawrence Berkeley stated that one irradiator source with all necessary shielding would fit inside of an 85-gal drum, but that it would cost $\$ 100,000$ to remove the source from the irradiator. Therefore, Lawrence Berkeley will need either a large Type B packaging or a heavily shielded smaller Type B packaging.

- Two new accelerators have recently opened and some targets with Type B quantities of radioactivity are expected to be produced. Some of those targets will be uncommon radionuclides which will need to be shipped to research facilities offsite and will require Type B packaging to ship them. Lawrence Berkeley was provided with information by WHC about how to access the Radioactive Materials Packages (RAMPAC) Database to assist their search for available packagings. 
- Two 55-gal drums of TRU waste onsite will eventually need to be disposed of at WIPP. It is also expected that their new accelerator will produce TRU waste during normal operations. Lawrence Berkeley is not set up to handle the TRUPACT-II packaging, so they are interested in using the Type B Drum packaging to meet their need.

- Some of the sources in the Pit Room at Lawrence Berkeley are in liquid form in small vials. Those sources will need to be analyzed before they can be disposed. If possible, Lawrence Berkeley would prefer to ship several vials of liquid in one package to the analysis facility. Lawrence Berkeley is interested in using the 500 $\mathrm{mL}$ version of the SafeSend ${ }^{\text {th }}$ for those shipments, if it is certified for use with Type A liquids.

\subsubsection{Lawrence Berkeley Packaging Issue}

Lawrence Berkeley is considering shipping two metric tons of excess depleted uranium and two metric tons of activated lead to Nuclear Metals, Inc. Nuclear Metals would be able to recycle that material and use it in their product line. However, since it appears that it will cost Lawrence Berkeley more to recycle this material at Nuclear Metals than it would to dispose of it, this material may not be recycled at Nuclear Metals. Lawrence Berkeley also expects to generate a large amount of slightly activated metal from their decontamination and decommissioning activities that will also face the same decision.

\subsection{FUTURE FY 1995 NEEDS ASSESSMENT ACTIVITY}

The Packaging Operations and Development Group plans to continue site visits with the same format over the remainder of FY 1995. Among the larger facilities that should be visited are Nevada Test Site, Pinellas Plant, Kansas City Plant, Portsmouth, Paducah, and Sandia National Laboratory - Albuquerque. Several other smaller research and development facilities may also be visited. By the end of FY 1995, all of the largest DOE facilities should have had an initial Needs Assessment visit. Beyond the end of FY 1995, more detailed visits to larger sites may be required to ensure that long-term packaging needs have been addressed. The initial site visits have included personnel aware of existing or near-term packaging needs, but have not included personnel cognizant of long-term packaging needs. Including DOE-HQ and strategic planners at each site, as well as representatives from site organizations that may have long-term packaging needs that have yet to be considered (e.g., a laboratory which has never shipped anything other than samples that is scheduled to be decommissioned in three years), will ensure that all required packagings are available when they are needed. 


\subsection{CONCLUSIONS}

The site visit format has been very effective to date. The sites visited have been cooperative and forthcoming with their packaging needs and developments. Visiting each site, in lieu of having one large meeting with attendees from each site, allows participation by site organizations not fully devoted to transportation and packaging, such as Waste Management and Environmental Remediation. This increases the input from each site and provides for greater participation.

The Needs Assessment has ascertained that all DOE facilities visited to date have packaging needs that cannot be satisfied by existing packagings. These facilities perceive that centralization of packaging across the DOE Complex and greater coordination of DOE facilities would improve efficiency and cost-effectiveness. The following were identified by the Needs Assessment as the most prevalent packaging needs and issues within the DOE Complex.

- Centralization and coordination of all packaging activities - this should include packaging development, inventories of existing packagings, procurement of new packaging, Quality Assurance reviews of packaging vendors through the SQIG program, POP testing, and determining a final disposition (e.g., recycling or disposing) for large inventories of slightly activated material such as stainless steel, and lead. A coordinated DOE approach to procuring Type A packagings now that POP regulations have displaced most DOT Specification packaging is also needed. This centralization and coordination would reduce duplication of effort by DOE facilities that are unaware of other ongoing development projects or existing packagings that could be used to satisfy their needs, would enable packagings and testing to be obtained at lower costs with bulk rate discounts, and coordinate items such as Quality Assurance reviews of vendors and recycling decisions so that these items would only have to be performed once instead of dozens of times by each DOE facility acting without knowledge of other DOE facility's decisions. Centralization and coordination of packaging activities across the DOE Complex would immediately improve their efficiency and cost-effectiveness.

- Packaging for laboratory samples - this includes packaging for Type A liquids, chilled hazardous liquid samples, and even Type B chilled samples. Samples are required to be chilled when Environmental Protection Agency Toxicity Characteristic Leaching Procedure tests have to be performed. Packagings have recently become available to ship Type $A$ and chilled hazardous liquid samples. The Type A liquid packaging was developed as a direct result of this Needs Assessment activity.

- POP for explosives - the Multipurpose Explosive packagings under development at this time should satisfy this need. 
- Packaging for TRU - this includes new packagings for plutonium metal and plutonium oxide, which are being developed by Savannah River as the 9972-9975 containers. The need for TRU packaging also.includes packaging that will overpack existing containers of TRU waste and prevent repackaging of that waste at each site. The overpack could be used to transport the waste that needs repackaging to a central location where it can be placed into a form that meets the WIPP waste acceptance criteria.

- Heavily shielded Type B packaging - this packaging would be for accelerator targets generated for research and development experiments and for older sources that are stored at facilities across the DOE that no longer have certified packaging. Any packaging developed for these needs would have to be able to ship a wide variety of contents, since many of the accelerator targets generated and older sources are one-of-a-kind in nature (unusual radionuclide composition).

- Radioactive liquid packaging with capacities of four liters (one gallon) or greater - at present, there is no available packaging certified for offsite use that can ship more than one liter (.3 gal) of radioactive liquid. The PAS- 1 cask is undergoing the certification process to be able to ship up to four liters (one gallon) of Type B liquid, and three DOE sites are in the process of purchasing the LR-56 packaging that can ship up to 4,000 L (1,057 gal) of Type A radioactive liquid offsite and Type B liquid onsite. The PAS-1 is expected to be certified by Summer 1995 and the first LR-56 should be delivered by December 1995. However, there is no other packaging development effort underway that will specifically be able to ship 55-gal drums of radioactive liquid, which is a widespread DOE need.

- Type B packaging for large volume items - several facilities have boxes containing Type B quantities of waste (mainly TRU) that are at least $1.2 \mathrm{~m} \mathrm{x} 1.2$ $\mathrm{m} \times 2.4 \mathrm{~m}$ ( $4 \mathrm{ft} \times 4 \mathrm{ft} \times 8 \mathrm{ft}$ ). The Super Tiger container has a NRC certification and a large enough cavity, but cannot be fabricated anymore. A replacement packaging would allow these large Type B items to be shipped to either a central location for repackaging into containers that fit inside of the TRUPACT II container (which would reduce the number of sites required to repackage the waste) or actually shipped to WIPP if its waste acceptance criteria is changed to permit use of packagings other than the TRUPACT II or the NuPac 72-B.

- Type B packaging for tritium - packagings for pure tritium and tritium contaminated waste are needed. Tritium is especially difficult to package due to its easily transportable nature. Two Type B packagings are currently certified for the shipment of pure tritium, the UC- 609 and LP-50, but both of those packaging designs are over 20 years old, no more of them can be fabricated, and have a limited remaining useful life. At present, no Type B packaging exists that can ship 55-gal drums or larger packages of waste with tritium contamination. The facilities that have this waste would prefer to avoid repackaging this waste into smaller packages. 
Most of these packaging needs are needed to support environmental cleanup activities across the DOE Complex. These activities fall within the scope of DOE Office of Environmental Management programs. The heavily shielded packaging for accelerator targets is needed to support the ongoing DOE Office of Energy Research program, while the POP for explosives and the bulk tritium packaging are required to support the DOE Office of Defense Programs.

The Needs Assessment activity has found several packaging developments, including the INEL Concrete Box, Multipurpose Explosive Packaging, Type B Drum, and Savannah River 9972-9975 plutonium packagings, that could be used throughout the DOE Complex to satisfy many of the needs described in this report. It has also initiated other important developments including the Type A laboratory sample packaging family that is currently being developed by the Packaging Operations and Development Group. The Needs Assessment has the potential to lead to many more packaging developments efforts by several different facilities within the DOE Complex. Finally, the Needs Assessment activity has opened up communication pathways between various DOE sites that should help sites pool their resources and improve efficiency. This rewarding activity should help the

DOE Complex, as a whole, become more efficient in transportation and packaging.

\subsection{RECOMMENDATIONS}

All DOE packaging activities should be centralized into one organization. This centralization would result in an immediate cost savings to DOE and increase the efficiency of all DOE packaging activities. For example, development of one Type B packaging system costs millions of dollars, while each Type A and low specific activity packaging development costs several thousand dollars, at a minimum. A centralized organization would be able to minimize the number of costly new packaging developments by ensuring that, when practical, existing packagings are modified for new uses, which is generally much less expensive than building a new packaging from scratch, or by ensuring that each new development meets as many different needs as possible. A central organization would coordinate procurement of packagings such as standard 55-gal drums so that even the smallest DOE facility can obtain bulk rate discounts when their order is combined with the orders of several different facilities. A central organization would rely on SQIG's Quality Assurance inspections of packaging vendors, and prevent repeated Quality Assurance inspections of the same vendor by several different DOE facilities. The central organization would also be able to make and enforce formal policy decisions. (e.g., whether to recycle or dispose of the thousands of tons of slightly activated material that exist throughout the DOE Complex)

The Needs Assessment activity should continue for the foreseeable future, regardless of whether all DOE packaging activities are centralized. If centralization occurs, the information gathered from the Needs Assessment will ease the transition to a central organization. If centralization does not occur, the Needs Assessment will still be able to improve the efficiency and cost-effectiveness of DOE packaging activities. Currently, many 
sites are developing packaging of their own and, in many cases, have no knowledge of how that packaging could be used at other sites. This can, and does, lead to a duplication of effort by several sites. Continued visits to sites developing packaging would allow DOE to determine which sites have packagings that could be of use to other sites. DOE can also coordinate that development and ensure that the needs of as many sites as possible are addressed. Smaller sites, in general, do not have enough packaging resources of their own to develop their own packaging, so they typically outsource all packaging development activities to commercial vendors. Informing smaller sites of ongoing packaging developments within the DOE and ensuring that already available packagings are used before new packagings are developed in the commercial sector will also reduce costs across the DOE. These functions will make all DOE transportation and packaging activities more efficient and productive.

The Needs Assessment activity should also be expanded to involve the long-range planners at each site and at DOE-HQ. Presently, the visits have, in general, only included personnel aware of the immediate and short-term packaging needs at each site. Therefore, only the current and short-term packaging needs of each site have been included. Expanding the scope of the visits to include long-range planners at each site, and at the DOE-HQ level, would enable DOE to determine what the future packaging needs are. It would also prioritize development of those packagings, along with any technology required to support development, and ensure that the required packagings are available when needed.

\subsection{REFERENCES}

DOE/RL, 1994, Needs Assessment Activity Report, DOE/RL-94-106; Revision 1, U.S. Department of Energy, Richland, Washington.

DOT, 1989, Transportation Regulations; Compatibility with Regulations of the International Atomic Energy Agency; Notice of Proposed Rule, Docket HM-169A, U.S. Department of Transportation, Washington, D.C.

LANL, 1994, Letter BUS-6:95-129 dated December 11, 1994, Los Alamos National Laboratory, Los Alamos, New Mexico.

Resource Conservation and Recovery Act of 1976, 42 USC 6901 et seq.

WHC, 1994, Test and Evaluation Document for DOT Specification 7A Type A Packaging, WHC-EP-0558, Westinghouse Hanford Company, Richland, Washington. 


\section{DISTRIBUTION}

Number of copies

OFFSITE

3

U.S. Department of

Energy,

Headquarters 19901 Germantown Road

Gaithersburg, Maryland 20874-1290

L. G. Blalock

EM-26

E. B. McNeil

EM-26

M. J. Conroy

EM-26

ONSITE

3

U.S. Department of Energy,

Richland Operations Office

R. F. Guercia R3-80

D. W. Claussen S7-55

RL Public Reading Room H2-53

$1 \quad$ Pacific Northwest Laboratory

Technical Files P8-55

48 Westinghouse Hanford Company

W. S. Edwards (40) G2-02

T. Romano G2-02

T. M. Kaufman G2-02

J. C. McCoy G2-02

Correspondence Control A3-01

Central Files L8-04

Information Release

Administration (3) L8-07 
DOE/RL-95-43 REV 0

This page intentionally left blank.

Distr-2 